Original Research Paper

\title{
Increasing Conceptual Understanding through CCM-CCA Based Learning Device
}

\author{
Muh. Makhrus ${ }^{1 *}$, Muhammad Zuhdi', Wahyudi', Muhammad Taufik ${ }^{1}$ \\ ${ }^{1}$ Physics Education Department, Faculty of Mathematics and Science Education, University of Mataram, Indonesia
}

DOI: $10.29303 /$ jppipa.v6i1.347

Sitasi: Makhrus, M., Zuhdi, M., Wahyudi, Taufik, M. 2020. Increasing Conceptual Understanding through CCM-CCA Based Learning Device. Jurnal Penelitian Pendidikan IPA (JPPIPA). 6 (1). pp. 81-84

Article history

Received: November $2^{\text {st }}, 2019$

Revised: December $12^{\text {st }}, 2019$

Accepted: December 24 $4^{\text {st }}, 2019$

*Corresponding Author: Muh. Makhrus: Physics Education Department, Faculty of Mathematics and Science Education University of Mataram, Mataram, Indonesia Email:

makhrus.fkip@unram.ac.id

\begin{abstract}
Learning must be focus on creating conceptual change in students. One of the alternatives is using CCM-CCA-based learning devices because CCM-CCA is a learning model that can create cognitive conflict as a condition for conceptual change. This research is directed to develop learning devices based on CCM-CCA that can improve conceptual understanding. The learning devices developed to consist of LEU (Learning Events Units) and SW (Students' Worksheet) for Newton's Law material about motion and work-energy. The results of the validation of learning devices (LEU and SW validation) indicate that these devices are valid in content and construction so that they are suitable for the learning process. Based on the results of the implementation of the device and the test results, it was concluded that the CCM-CCA-based learning device was able to improve conceptual understanding. The increase was obtained through an N-Gain analysis with an N-Gain value for LEU of $60.44 \%$ and SW of $54.01 \%$. The percentage of the N-Gain score is included in the increase with the medium category.
\end{abstract}

Keywords: Conceptual Understanding; CCM-CCA; Learning Device.

\section{Introduction}

One of the main focuses of education to face the development of the industrial revolution 4.0 is the development of 21 st century skills consisting of communication, collaboration, critical thinking and problem solving, creative and innovative. As a result, learning cannot only be focused on being limited to the ability to answer problems mathematically. There is a need for meaningful learning that is able leads students to understand concepts. Conceptual change has become a general conception in meaningful learning. Posner et al. (1982) suggested that conceptual change can be in the form of an expansion of the scheme (assimilation), but this does not guarantee the loss of wrong understanding in students' minds. The second alternative is accommodation or reconstruction. These accommodations tend to be more instrumental in correcting concept errors in students.

Among various conceptions of meaningful learning, other research communities such as psychology, learning, science and mathematics education focus their attention on conceptual change
(Vosniadou, 1999; Sinatra \& Pintrich, 2003 in Jonassen et al., 2005). Cognitive conflict-based learning allows students to convey their initial conceptions and criticize concepts that are different from their conceptions, to be able leads students to change their conceptual in to more complete and more scientific (Makhrus, et al., 2018; Rahim, et al., 2015). This definition shows that conceptual change is not only limited to socio-cultural interactions or teaching strategies but as a process of identifying misconceptions and helping them to change these misconceptions into new concepts that are more useful, reasonable, and understandable.

Conceptual change is difficult to perform if learning is not directed at a state of contradiction (cognitive conflict). Makhrus (2018), Presentation of cognitive conflict causes students to compare the knowledge possessed with the knowledge conveyed by the instructor. Finally, students do not have confidence in the truth of their preconceptions, so there is a conceptual change. Based on these problems, learning needs to be supported by learning devices based on the CCM CCA (Conceptual Change Model with Cognitive 
Conflict Approach) that can improve students' understanding of concepts.

\section{Methode}

This type of research is $\mathrm{R} \& \mathrm{D}$ which refers to Gall \& Borg. The R\&D stage according to Gall \& Borg (2003) includes 10 stages, but this study was adapted into 4 stages, i.e.: 1) preliminary study, 2) preparation of CCM-CCA learning devices, 3) validation of CCM-CCA learning devices, 4) implementation CCM-CCA learning device.

The devices developed in this study have been validated through FGD activities and their reliability is measured and analyzed using the Percentage of Agreement. Improved understanding of students' concepts was analyzed by the N-Gain test to find out how much improvement before and after learning with the CCM-CCA-based devices. N-Gain Test aims to find out how much understanding increase of the concept after being given treatment. Hake (2002), Calculating the value of N-Gain used the following formula.

$$
\mathrm{g}=\frac{(\% \text { posttest }-\% \text { pretest })}{(100-\% \text { pretest })}
$$

$\mathrm{N}$-Gain can be interpreted as the following table.
Table 1. Interpretation of $N$-Gain

\begin{tabular}{lll}
\hline No & $N$-Gain Grade & Categori \\
\hline 1 & $(\mathrm{~g})>70 \%$ & High \\
2 & $30 \% \leq\langle\mathrm{g}\rangle \leq 70 \%$ & Moderate \\
3 & $(\mathrm{~g})<30 \%$ & Low \\
\hline
\end{tabular}

\section{Result and Discussion}

The device developed in this study has been validated in terms of content and construct and stated that the device is feasible to be applied in learning. (Validation results see Table 1). The advantage of CCM-CCA-based learning devices can change the students' conceptual because of the confrontation or cognitive conflict on each device that increases curiosity and the process of finding the truth of the concept. This is consistent with the statement of Broughton, Sinatra, \& Reynolds (2007); Guzetti, Snyder, Glass, \& Gamas (1993) in Chi (2008) that the wrong concept in the subject matter can be corrected when students are explicitly confronted with correct information through contradiction and refutation. This shows that cognitive conflict plays an important role or effect in conceptual change. Lee et al. (2003) and Kwon (1997) in Baser (2006 :), state about the need and importance of cognitive conflict to conduct conceptual change.

Table 2. Validity and Reliability of Learning Devices based on CCM-CCA

\begin{tabular}{llll}
\hline Learning Devices & Validity Score & Reliability Score & Note \\
\hline LEU (Learning Events Units) & 3,52 & 96,01 & Valid and Reliable \\
SW (Students' Worksheet) & 3,43 & 92,75 & Valid and Reliable \\
\hline
\end{tabular}

The instrument used to determine student understanding of conceptual is a concept understanding test. The data obtained were analyzed using descriptive statistics and the percentage of NGain (improvement) in understanding students' concepts. The test in this study includes a pre-test given before learning to find out the basis of students' understanding of the concept of "Newton's law, Works, and Energy" and a final test (post-test) to find out the understanding of student concepts as indicated by the loss of misconception on the results of student answers. The results of a brief analysis can be seen in Table 3 below.

Table 3. Test Results of Student Understanding of Concept

\begin{tabular}{llllll}
\hline \multirow{2}{*}{ No } & \multirow{2}{*}{ Topics } & \multicolumn{2}{l}{ Score Rate } & \multirow{2}{*}{ N-Gain Score } & Category \\
\cline { 3 - 5 } & T1 & T2 & $60,44 \%$ & Medium \\
2. & Newton's Laws & 41,66 & 76,92 & $54,10 \%$ & Medium \\
\hline
\end{tabular}

Note: $\mathrm{T} 1=$ Pre-test; $\mathrm{T} 2=$ Post-test.

Based on Table 3 it is known that the learning devices based on CCM-CCA can improve understanding of the concept. Based on the table above, it is known that the percentage of N-Gain in Newton's Laws topic is $60.44 \%$, while for Work and Energy topic is $54.10 \%$. The percentage of N-Gain is included very high because of $\langle\mathrm{g}\rangle \geq 0.7$ (Hake, 1998). This is happening because students are able to understand the abstract concepts better and have undergone conceptual changes from misconceptions.
Students have been given problems and new information that contradicts their understanding at the beginning of learning, so students experience an imbalance in cognitive structure. This situation makes students more challenged to prove the truth of new information conveyed by lecturers through literature studies, discussions, and proof through experiments. This is different from learning in general which from the beginning of direct learning is taught the correct theories and concepts about a problem without seeing 
the imbalance of cognitive structures occurred in students, because the theories and concepts taught are different from the initial conceptions owned by students. Setyowati et al., (2011), states that the cognitive conflict approach is able to foster critical thinking skills, improve understanding of concepts, and learning outcomes. The level of certainty of student response shown in the following table.

Table 4. Response Certainty Grade of Students' Answer

\begin{tabular}{lllllll}
\hline \multirow{3}{*}{ Item } & \multicolumn{9}{l}{ Category (Students) } & \multicolumn{3}{l}{ MTC } \\
\cline { 2 - 7 } & NC & \multicolumn{3}{l}{ MC } & \multicolumn{3}{c}{ U1 } \\
\cline { 2 - 7 } & U1 & U2 & U1 & U2 & U1 & U2 \\
\hline 1 & 11 & 2 & 8 & 3 & 1 & 15 \\
2 & 11 & 1 & 9 & 1 & 0 & 18 \\
3 & 8 & 2 & 12 & 1 & 0 & 17 \\
4 & 7 & 4 & 10 & 2 & 3 & 14 \\
5 & 10 & 2 & 7 & 2 & 3 & 16 \\
6 & 12 & 1 & 7 & 3 & 1 & 16 \\
Averages & $\mathbf{9 , 8 3}$ & $\mathbf{2 , 0 0}$ & $\mathbf{8 , 8 3}$ & $\mathbf{2 , 0 0}$ & $\mathbf{1 , 3 3}$ & $\mathbf{1 6 , 0 0}$
\end{tabular}

Note: U1: Pretest; U2: Posttest; NC: No Conception; MC: Misconception; MTC: Mastering True Conception

The results of the initial test (pretest) in table 4 shows that all the students do not understand the concept. Most students do not understand the concept and most are experiencing misconceptions. The most misconceptions occurred to the students is the concepts of Newton's laws topics (tests number 1 to 3 ). Students are still confused with the law of inertia and the law of action. The results of the final test (post-test) shows the level of understanding of student concepts has increased, this is indicated by decrease of the students who experience not understanding concepts and misconceptions. Figure 1 below is a comparison of the average level of certainty of the responses of students in the pretest (T1) with posttest (T2) for the category of not understanding the concept (NC), misconception (MC), and mastering the true concept (MTC).

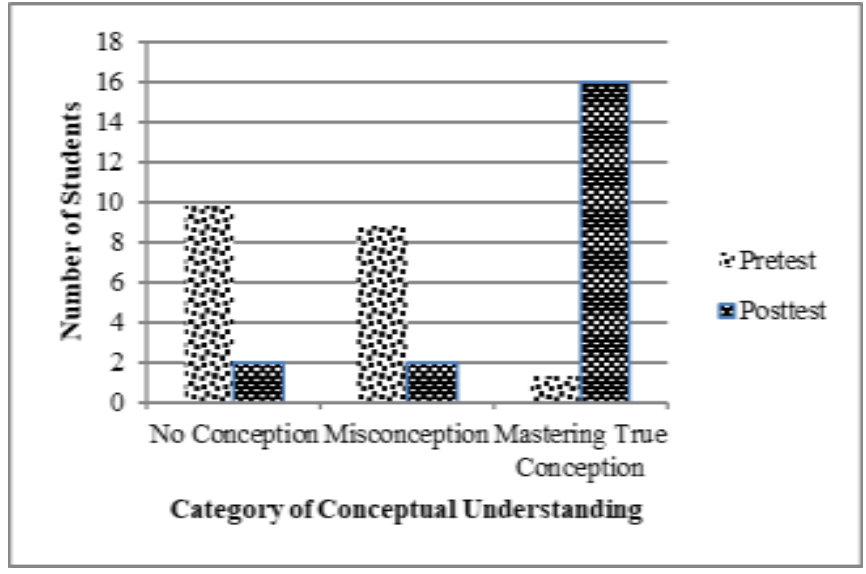

Figure 1. Comparison of the average level of certainty of response

Figure 1 shows that in the initial test results (T1) of students who experience the category do not understand the concept (NC) and misconception (MC) are far greater than the number of students on the final test results (T2). Whereas in the category of conceptual understanding the opposite occurs, namely the results of the final test are far greater than the results of the initial test. These results indicate that learning equipped with CCM-CCA-based devices can improve concept understanding. These results also indicate that, this study was successful in accordance with the expected goals. The successful use of CCM-CCAbased learning devices is due to the fact that in the learning process the students seeking their own knowledge (activities in SW), it will make students more active in solving problems related to the contradictions experienced. The knowledge that students get can't be separated from the knowledge that has been obtained previously. Maintaining the relationship between old knowledge with knowledge that will be received by students to form new knowledge is very important. Through the process of assimilation and accommodation, students are able to link their initial knowledge with more complete scientific knowledge/concepts. In accordance with the opinion of Makhrus et al. (2014) states cognitive conflict will connect students in active learning. The learning process undertaken makes students make reasoning over their preconceptions and estimates to explain the strategies that will be used in solving these problems. According to Hidayatullah et al. (2018) cognitive conflict can be used as an alternative in learning, because it can improve students' thinking skills. Students who are aware of the incompatibility between scientific concepts with the initial concept will try to solve the problem. This cognitive conflict occurs after students carry out activities at the SW and feel a state of contradiction with their knowledge. The results of this study reinforce the findings of Baser (2006) which states that cognitive conflict can improve conceptual understanding.

\section{Conclusion}

Based on the results and discussion, it was concluded that the CCM-CCA-based learning tool developed was able to improve students' understanding of concepts related to Newton's laws, Works, and Energy.

\section{Recommendation}

CCM-CCA based learning divices on Newton's law material about motion and work-energy have been able to improve students' understanding of concepts. Therefore it is necessary to develop learning tools on other materials in learning universal physics to improve students' understanding of concepts. Learning in universal physics courses using CCM-CCA based learning divices will be able to help students experience conceptual changes to the wrong 
conceptions that students have into scientific conceptions.

\section{References}

Baser, M. (2006). Fostering conceptual change by cognitive conflict based instruction on students' understanding of heat and temperature concepts. Eurasia Journal of Mathematics, Science and Technology Education, 2(2).pp. 96-114.

Chi, M.T.H. (2008). Three types of conceptual change: Belief revision, mental model transformation, and categorical shift. In S.Vosniadou (Ed.), Handbook of research on conceptual change (pp. 61-82). Hillsdale, NJ: Erlbaum

Gall, M. D. \& Borg. (2003). Educational Research. Boston: Pearson Education, Inc.

Hake, R. R. (2002). Relationship of Individual Student Normalized Learning Gains in Mechanics with Gender, High-School Physics, and Pretest Scores on Mathematics and Spatial Visualization. Submitted to the Physics Education Research Conference; Boise, Idaho; August 2002.

Hidayatullah, Z., Makhrus, M., \& Gunada, I. W. (2018). Analisis Tingkat Kemampuan Berpikir Kritis Gelombang Mekaanik melalui Pembelajaran dengan Pendekatan Konflik Kognitif. Jurnal Pendidikan Fisika dan Teknologi, 4(2).pp. 151-157.

Jonassen, D., Strobel, J., \& Gottdenker, J. (2005). Model building for conceptional change. Interactive Learning Environments, 13(12).pp.15-37.

Makhrus, M. (2018). Efektivitas Model Pembelajaran CCM CCA untuk Memfasilitasi Perubahan Konsep Gaya Pada Mahasiswa. Jurnal Pendidikan Fisika dan Teknologi, 4(2).pp. 253-261

Makhrus M., Nur M., dan Widodo W. (2014). Model Perubahan Konseptual dengan Pendekatan Konflik Kognitif. Jurnal PIJAR MIPA, 9(1).pp. 20-25.

Rahim, R. A., Noor, N. M., \& Zaid, N. M. (2015). Meta-analysis on Element of Cognitive Conflict Strategies with a Focus on Multimedia Learning Material Development. International Education Studies, 8(3).pp. 7378.

Setyowati, A., Subali, B., dan Mosik. (2011). Implementasi pendekatan konflik kognitif dalam pembelajaran fisika untuk menumbuhkan kemampuan berpikir kritis siswa SMP kelas VIII. Jurnal Pendidikan Fisika Indonesia, 7(2).pp. 89-96.

Posner, S., Hewson \& Gertzog. (1982). accomodation of a scienific conception: toward a theory of conceptual change. Department of Education, Cornell University, Ithaca, New York.

Vosniadou, S. (1999). Conceptual change research: The state of the art and future directions. In W. Schnotz, S. Vosniadou, \& M. Carretero (Eds.), New perspectives on conceptual change (pp. 1-13). Amsterdam, The Netherlands: Pergamon. 